ISSN No. 0974-035X

An Indexed, Refereed \& Peer Reviewed Journal of Higher Education

\title{
LEARNING STRATEGIES AND STYLES IN THE SECOND LANGUAGE LEARNING
}

\section{Mr. Hitendra H Vyas}

\section{Second Language Learning:}

SLA is an expanding, and diverse field. SLA theories have a variety of origins and differ substantively. In many ways, these theories are "interim understandings" of how people learn second languages. All SLA theories are designed to facilitate the process of second language learning and teaching and likely to be relevant to language teaching practice in one way or another. SLA is defined by Michael Long:

Second language acquisition is a field of study which generates and tests theories concerning the acquisition of languages other than $L 1$ in many different contexts, including - but not mainly - the foreign language classroom. (in Byram, M. 2000, p. 527)

\section{Learning Strategies:}

The notion of special learner techniques or strategies as helpful to second language acquisition was first introduced in SLA literature by Rubin (1975) and Stern (1975). An extensive research in Psychology on the influence of learning strategies on reading comprehension and problem solving had already taken place but there was little or no interaction between SLA and psychology so far as the study of second language learning strategies was concerned (O’Malley and Chamot 1990). Rubin (1975) suggested that the "good language learner" might be doing something special or different and that we could learn from the successful language learner's use of special techniques or strategies. This idea of learner strategies contrasted with the simplistic ideas such as "ear for the language" or talent for language learning. 


\section{Hitendra Vyas / Page 233-243}

Research indicates that language learners at all levels use learning strategies (Ehrman and Oxford 1989). Learning strategies influence the degree of proficiency obtained in a second language. Research also reveals that more effective learners employ more appropriate and a wider range of strategies than do less effective learners. Mc Donough (1995) has posited some important questions concerning learning strategies: When is a strategy good? Where do strategies come from? Does teaching learning strategies produce better learners? The answers to these questions would be useful in understanding the basics of strategy research. Strategies are not good or bad in themselves. They may be good for some students and for some specific tasks. Learning strategies vary with the task, learning stage, age of the learner, the learning context, individual learning styles, and so on (Rubin 1975). Strategies are like "battle plans" and there may be a number of ways to solve a particular problem and the learner has to choose one or some of them to attack the problem at hand (Brown 1987). One strategy may work for a certain student in a particular situation but not for another in the same situation. Effective learners employ strategies that are suitable to their needs and to them as language learners.

Wenden (1978 in Aninao 1993) offers some useful criteria for characterizing a learner strategy. These include - a) that the term "strategy" refers to specific actions or techniques a learner utilizes; b) that strategies can be observable; c) that learners make use of them for purposes of solving problems; and d) that strategies are amenable to change (through training or in course of the learning process). Chesterfield and Chesterfield (1985 in Larsen-Freeman 1991) have demonstrated that learners' strategies do change over time.

Rubin (1975) defines learning strategies as "techniques or devices, which a learner may use to acquire knowledge." According to Bialystok (1978 in Larsen-Freeman and Long 1991) strategies are "optimal means for exploiting available information to improve competence in a second language." Oxford (1990 in Parry and Stansfield- eds.) defines learning strategies as "steps or actions taken by language learners to enhance any aspect of their learning: accession, storage, retrieval and use of information."

Brown (1978) defined strategies as "specific methods of approaching a problem or task, modes of operation for achieving a particular end, planned design for controlling and manipulating certain information." He states that strategies vary "intra-individually", that is, within an individual whereas learning styles differentiate one individual learner from another. "A learning strategy is any action that language learners perform in order to increase their 
target language proficiency" (Byram 2000). Strategy may be focused on a specific task (e.g. learning a vocabulary item or a grammatical rule) or it may also deal with the language learning process in general. Each learner may use one or more learning strategies at different times depending on a range of variables such as the nature of the learning task, motivation levels, and experience.

According to Dansereau (1985 in Harlow 1988) strategies are "a set of processes or steps that can facilitate the acquisition, storage and/or utilization of information." O'Malley and Chamot (1990) distinguished between study skills and strategies. Study skills describe overt behaviour, such as taking notes, writing summaries, and so on. Learning strategies, on the other hand, refer to mental processes, which are not directly observable. They add, however, that the distinction between study skills and strategies is theoretically important, but it is not always necessary to differentiate between them in practice. They define learning strategies as "special ways of processing information that enhance comprehension, learning or retention of the information."

Anderson (1983) proposed a 'unitary' theory of mind or a common cognitive system for all higher-level mental processes. Language is viewed as a complex cognitive skill and, therefore, can be described within the context of cognitive theory (O'Malley et al. 1990). In Anderson's framework of cognitive theory, strategies can be represented in the same way as any other complex cognitive skill such as chess or maths. Complex cognitive skill, according to Anderson, refers to "the ability to perform various mental procedures." Declarative knowledge is maintained in long-term memory in terms of "meaning based concepts" - definitions of words, facts, rules and so on. It can also be in form of images or "temporal strings" - i.e., order of events. One is able to describe the contents of declarative knowledge.

Procedural knowledge, according to Anderson, is represented in memory by "production systems." In its most basic form, a "production system" has a 'condition' and an 'action.' The condition contains a clause or a set of clauses preceded by IF, and the action has a clause or a set of clauses preceded by THEN. Strategy applications resemble production systems with a condition (IF) and one or more (THEN) action clauses. An example cited by O'Malley et al. (1990) is as follows:

"If the goal is to comprehend an oral or a written text, and I am unable to identify a word's meaning, Then I will try to infer the meaning from the context." 


\section{Hitendra Vyas / Page 233-243}

Production systems are initially represented like declarative knowledge but may become automatic through repeated practice. Production systems have been used to describe procedural knowledge in reading, mathematical problem solving, and chess as well as language comprehension and production. Procedural knowledge underlies our ability to understand and produce (generate) language. Procedural knowledge such as language skill is acquired gradually and only with extensive opportunities for practice. Declarative knowledge or factual information may be acquired relatively quickly. Anderson discusses three stages of the process by which a complex cognitive skill is acquired. The three stages are as follows:

(a) Cognitive Stage: Skill learning generally begins with this stage. Learners are taught how to do the task, observe an expert performing it, and are consciously involved in learning it. The performance of the learner at this stage is rule-based, deliberate and tends to be laden with errors. The knowledge acquired at this stage is declarative and can be verbally described by the learner. For example, we may memorize vocabulary or the rules of grammar to speak a second language or try to use an unanalyzed chunk of language.

(b) Associative Stage: During this stage connections among the various components or elements of the skill are strengthened. Actions are executed more rapidly and errors begin to diminish. The declarative knowledge is gradually turned into procedural form. However, the declarative representation that we formed initially is not totally lost. For example, we may become more fluent at speaking a foreign language, but we still remember the rules of grammar.

(c) Autonomous Stage: At this stage performance of skill becomes increasingly fine-tuned. Actions are performed more easily and the original rules governing the performance may no longer be retained. There is much less demand on working memory or consciousness and the skill can often be executed effortlessly. For example, as we become more proficient in a second language, we are able to comprehend or produce utterances with little difficulty. A complex skill such as second language acquisition can only be mastered after a relatively long period of time.

O'Malley et al. (1985) suggest that learning strategies are declarative knowledge which may become procedural through practice. Learning strategies are conscious and deliberate when they are in the Cognitive and Associative stages of learning but are applied automatically and 
often without awareness in the autonomous stage. Strategies may become automatic after repeated use or after a skill has been fully acquired.

An important contribution of Cognitive Psychology to SLA is the formulation of learning strategies in an "information-processing" theoretical model. This model contains an executive or metacognitive function in addition to operative, or cognitive - processing function. Metacognitive strategies involve thinking about the learning process, planning for learning, monitoring of comprehension and production of language while it is taking place, and selfevaluation of learning after the learning activity is completed. Cognitive strategies are more directly related to individual learning tasks and entail direct manipulation of the learning materials.

A third type of learning strategy identified in the literature on cognitive psychology concerns the influence of social and affective processes on learning a second language. Examples of social and affective strategies are: co-operative learning, asking questions for clarification, and self-talk etc. O'Malley et al. (1990) place a greater emphasis on metacognitive strategies. They state, 'Students without metacognitive approaches are essentially learners without direction or opportunity to plan their learning, monitor their

progress, or review their accomplishments and future learning directions.'

Rubin (1975) observed second language classrooms and talked to "Good Language Learners." She approached the teachers of these students to elicit their observations on the use of language learning strategies. In her later research, she (1981) employed a variety of methods to collect data on the second language learners' use of learning strategies. These included - 50 hours of classroom observation, observation of a small group of students working on a stripstory, less directed self-reports from a few students, and directed diary (journal) writing of two students. Observation of a regular classroom yielded meagre results. Rubin (1975) compiled a list of seven strategies. The Good Second Language Learner -

1 . is a willing and accurate guesser.

2. has a strong drive to communicate, or to learn from a communication. He is willing to do many things to get his message across.

3. is often not inhibited. He is willing to appear foolish if reasonable communication results.

4. is constantly looking for patterns in the language (attends to form in addition to focusing on communication). 


\section{Hitendra Vyas / Page 233-243}

5. Practices. He may practice pronouncing words or making up sentences.

6. Monitors his own and the speech of others.

7. Attends to meaning. He knows that in order to understand the message, it is not sufficient to pay attention to the grammar of the language or to the surface form of speech.

\section{Learning Styles:}

The concept of learning styles is based primarily on the work done by Noel Entwistle (1983). He reports on a number of studies in the area of learning strategies adopted by various learners across school curriculum. Drawing upon his vast experience in educational psychology, Entwistle postulates that each individual learner brings with him / her a range of psychological traits according to which the learning task is processed by the person. It would be possible to gain an insight into the overall learning style of a person by focusing on the learning strategies adopted by him / her on various occasions. The term learning style has been used to describe "an individual's natural, habitual, and preferred way of absorbing, processing, and retaining new information and skills" (Reid 1995 cited in Lightbown, Pasty and Nina Spada 2008).

The notion of learning styles can be understood as a broad psychological construct, which encompasses the learning behaviour of each individual. While a learning strategy can be seen as the learning behaviour adopted by a learner for a short while in responding to a specific learning task, the learning style is a relatively more stable personality trait displayed by the individual in responding to several learning tasks over a period of time. Learners have clear preferences for how they go about learning a new language or language material.

Oxford (in Oxford, Rebecca and David Crookall 1989) reported a strong influence of general learning style on choice of language learning strategies. Oxford (1990 in Parry and Stansfieldeds.) also states that strategies employed by students usually reflect their typical learning styles. Lawrence (1984 in Oxford 1990) stated that the term learning style, among other learner traits, encompasses a disposition to use certain learning tools (i.e. strategies) and to avoid others. Entwistle (1983) states that 'the general tendency to adopt a particular strategy is referred to as a learning style.'

Attempts to define learning styles range from "definitional statements to elaborate categories of learning style elements" (Henson, K. et al. 1984). Gregorc (1979) views a learning style as "consisting of distinctive behaviors which serve as indicators of how a person learns from and 
adapts to his environment. It also gives clues as to how a person's mind operates." According to Hunt (1979 in Henson, K. et al. 1984) a learning style "describes how a student learns, not what he has learned." Keefe (1982 in Henson, K. et al. 1984) considers learning styles as "characteristic cognitive, affective and psychological behaviors that serve as relatively stable indicators of how learners perceive, interact with and respond to the learning environment."

According to Rita Dunn (1984) "Learning style is the way in which each person absorbs and retains information and/or skills; regardless of how that process is described, it is dramatically different for each person." Learning style relates to many of the characteristics of the individual learner. Scarcella et al. (1992) define learning styles as "the general approaches students use to learn a new language." They suggest that these are the same styles as they employ in learning many other subjects and in solving various problems.

According to Scarcella et al. (1992), four central dimensions of language learning styles are: a) Analytic-Global aspect; b) Sensory preferences; c) Intuition-sensory / Sequential learning; and d) the Orientation towards closure or openness. However, when there is no outward force or interference, "students typically use the learning strategies that reflect their basic learning style" (Ehrman and Oxford 1989). The term learning style, as pointed out by Ehrman (Ehrman 1990 in Parry and Stansfield- eds.), is often used to refer to "both cognitive style and other largely affective, internal variables that differentiate individuals from each other in their approach to learning." Learning styles are "information-processing preferences that affect the focus of attention of individual learners, the choice of learning activities to which students gravitate, and the kinds of experience that will enhance motivation, or increase anxiety." "The interaction of learning style and preferred learning strategies also bears heavily onto question of success in language learning.”

As Byram (2000) reports, learning styles are cognitive differences in the way in which individuals learn. A learning style is a relatively permanent, characteristic approach to a wide range of perceptual and intellectual activities, tasks, and situations. Learning styles have been investigated and described on the basis of polarities such as:

1. field dependence and field independence

2. holists and serialists (globalists and analysts) 
3. broad categorizers and narrow categorizers

4. data gatherers and rule formers etc.

Though many learning style assessment instruments have been developed in recent years, very little research has examined the interaction between different learning styles and success in second language acquisition. Lightbown and Spada (2008) reiterate the need for more research on learning styles in a way that would help us make teaching more suitable to language learners' preferred learning styles:

At a minimum, research on learning styles should make us skeptical of claims that a particular teaching method or textbook will suit the needs of all learners. 
Towards Excellence: An Indexed, Refereed \& Peer Reviewed Journal of Higher Education / Mr.

Hitendra Vyas / Page 233-243

\section{References:}

Byram, Michael, ed. Routledge Encyclopedia of Language Teaching and Learning. London: Routledge (Taylor and Francis Group), 2000. Print.

Larsen-Freeman, Diane. "Second Language Acquisition Research: Staking out the Territory.” TESOL Quarterly. Vol 25 No 2. 1991. 315-39. Print.

Brown, H. Douglas. Principles of Language Learning and Teaching. $2^{\text {nd }}$ ed. NJ: Prentice Hall, 1987. Print.

Mc Donough, Steven H. Psychology in Foreign Language Teaching. $2^{\text {nd }}$ ed. London: ELBS/ George Allen and Unwin, 1981. Print.

Henerson, Marlene, E., Lynn Lyon Morris, and Carol Taylor Fitz-Gibbob. How to Measure Attitudes. Beverly Hills: Sage Publications, 1985. Print.

Scarcella, Robin. C., and Rebecca. L. Oxford. The Tapestry of Language Learning: The Individual in the Communicative Classroom. Boston: Heinle and Heinle, 1992. Print.

Oxford, Rebecca, and Martha Nyikos. "Variables Affecting Choice of Language Learning Strategies by University Students." The Modern Language Journal. Vol 73 No 3. 1989. 291300. Print.

Entwistle, Noel. Styles of Teaching and Learning: An Integrated Outline of Educational Psychology for Students, Teachers and Lecturers. Chichester: John Wiley and Sons, 1983. Print.

Rubin, Joan. "What the "good language learner" can teach us." TESOL Quarterly. Vol 9 No 1. 1975. 41-51. Print.

O’ Malley, J. Michael, and Anna Uhl Chamot. Learning Strategies in Second Language Acquisition. Cambridge: Cambridge U P, 1990. Print.

Ehrman, Madeline, and Oxford, Rebecca. "Effects of Sex Differences, Career Choice, and Psychological Type on Adult Language Learning Strategies.” The Modern Language Journal. Vol 73 No 1. 1989. 1-13. Print. 
Mc Donough, Steven H. Strategy and Skill in Learning a Foreign Language. London: Edward Arnold, 1995. Print.

Aninao, Juan Cayetano, Jr. "Training High School ESL Students to Use Language Learning Strategies.” Diss. Stanford U, Stanford, 1993. Print.

Bialystok, Ellen. "The Compatibility of Teaching and Learning Strategies." Applied Linguistics. Vol 6 No 3. 1985. 255 - 62. Print.

Bialystok, Ellen. Communication Strategies. Oxford: Basil Blackwell Ltd, 1990. Print.

Oxford, Rebecca. "Styles, Strategies and Aptitude: Connections for Language Learning." Language Aptitude Reconsidered . Ed. Thomas. S. Parry and Charles. W. Stansfield. New Jersey: Englewood Cliffs, 1990. Print.

Anderson, J. R. Cognitive psychology and its Implications. San Francisco: Freeman, 1980. Print.

O’Malley, J. Michael, Anna Uhl Chamot, Gloria Stewner-Manzanares, Rocco P. Russo, and Lisa Kupper. "Learning Strategy Applications with Students of English as a Second Language.” TESOL Quarterly. Vol 19 No 3. 1985. 557-84. Print.

Reid, J.M. "The Learning Style Preferences of ESL Students.” TESOL Quarterly. Vol 21 No 1. 1987. 87-111. Print.

Oxford, Rebecca and David Crookall. "Research on Language Learning Strategies: Methods, Findings, and Instructional Issues." The Modern Language Journal. Vol 73 No 4. 1989. 404-19. Print.

Henson, Kenneth T. and Paul Borthwick. "Matching Styles: A Historical Look." Theory Into Practice. Vol 23 No 1. 1985. 3-9. Print.

Dunn, Rita. "Learning Style: State of the Science.” Theory Into Practice. Vol 23 No 1. 1985. 10-19. Print. 
Towards Excellence: An Indexed, Refereed \& Peer Reviewed Journal of Higher Education / Mr. Hitendra Vyas / Page 233-243

Ehrman, Madeline, and Oxford, Rebecca. "Adult Language Learning Styles and Strategies in an Intensive Training Setting”. The Modern Language Journal. Vol 74 No 3. 1990. 311- 27. Print.

Ehrman, Madeline. "The Role of Personality Type in Adult Language Learning: An Ongoing Investigation' In Thomas S Parry and Charles W Stansfield. Eds. Language Aptitude Reconsidered. New Jersey: Englewood Cliffs, 1990. Print.

www.wikipedia.org

\section{Hitendra H Vyas S. V. Arts College, Ahmedabad Email: hitendrahvyas@gmail.com}

